\title{
Analisis Pengetahuan Siswa melalui Pembelajaran Penemuan di Sekolah Dasar Pahlawan
}

\author{
Dini Xena Dista \\ Universitas Pahlawan Tuanku Tambusai \\ Jl. Tuanku Tambusai No.23 Bangkinang, Kampar, Riau \\ email: dini.bkn123@gmail.com \\ Ramdhan Witarsa \\ Universitas Pahlawan Tuanku Tambusai \\ Jl. Tuanku Tambusai No.23 Bangkinang, Kampar, Riau \\ email: drdadan19@gmail.com
}

Received: Dec 25, 2019 Revised: March 23, $2020 \quad$ Accepted: May 4, 2020

\begin{abstract}
The purpose of this study was to get an overview of the knowledge of Pahlawan Elementary School students about energy change. The research used a quantitative descriptive research method. In this research, inquiry learning is carried out on the subject of energy change. Throughout research, learning is based on inquiry learning that is linked to the environment. Overall students answered the questions given related to changes in energy and the environment. The results of what students think about these questions were analyzed and conclusions drawn. The results of this study indicate that students' knowledge in the Pahlawan Elementary School about energy change is still developing. This is indicated by several misunderstandings that occur continuously and repeatedly. The novelty of this research is the existence of a new step of inquiry learning that is different in theory in general. The implication of this research is the need to improve the ability of teachers to assist the implementation of inquiry learning,
\end{abstract}

Keywords: analysis, inquiry learning, knowledge

\begin{abstract}
Abstrak
Tujuan penelitian ini adalah untuk mendapatkan gambaran pengetahuan siswa Sekolah Dasar Pahlawan tentang perubahan energi. Metode penelitian yang digunakan adalah metode penelitian deskriptif kuantitatif. Dalam penelitian ini dilakukan pembelajaran penemuan pada bahasan perubahan energi. Sepanjang penelitian, pembelajaran didasarkan pada pembelajaran penemuan yang dikaitkan dengan lingkungan hidup. Keseluruhan siswa menjawab pertanyaan-pertanyaan yang diberikan berkaitan dengan perubahan energi dan lingkungan. Hasil dari apa yang siswa pikirkan mengenai pertanyaan-pertanyaan tersebut dianalisis dan ditarik kesimpulan. Hasil penelitian ini menunjukkan bahwa pengetahuan siswa di Sekolah Dasar Pahlawan tentang perubahan energi masih berkembang. Hal ini ditunjukan dengan beberapa kesalahpahaman yang terjadi secara terus
\end{abstract}


menerus dan berulang. Kebaruan penelitian ini adalah adanya langkah baru pembelajaran penemuan yang berbeda secara teori pada umumnya. Implikasi dari penelitian ini adalah perlu peningkatan kemampuan guru dalam mendampingi pelaksanaan pembelajaran penemuan, hal ini agar tidak terjadi salah konsep yang berkepanjangan.

Kata kunci: analisis, pembelajaran, penemuan, pengetahuan

\section{Pendahuluan}

Salah satu tantangan pada kehidupan saat ini yang dihadapi oleh sebagian besar manusia di seluruh dunia salah satunya adalah keberadaan energi dan keberlanjutannya. Sumber daya energi yang terbarukan masih sangat minim dikuasai oleh sebagian besar manusia. Penggunaan yang semakin hari semakin besar tidak diimbangi dengan keberadaan yang sesuai dengan kebutuhan energi saat ini ke depan ${ }^{1}$.

Salah satu jalan yang bisa kita lakukan segera adalah dengan cara penghematan energi. Bagaimana cara menghemat energi juga merupakan tantangan tersendiri bagi guru-guru dan orangtua. Orangtua dan guru perlu melakukan pendampingan mengenai bagaimana menghemat energi ${ }^{2}$.

Pendampingan bagaimana cara menghemat energi sebaiknya dilakukan sejak dini, mulai dari sekolah formal pada jenjang Sekolah Dasar. Siswa-siswa di Sekolah Dasar yang telah memiliki pengetahuan dan keterampilan mengenai hemat energi akan berdampak besar pada kualitas hidup mereka baik dalam jangka pendek maupun jangka panjang ${ }^{3}$.

1 C. BOYLAN, 'Exploring Elementary Students' Understanding of Energy and Climate Change', International Electronic Journal of Elementary Education, 1.1 (2008), 1-15.

2 I. J. Ratinen, 'Primary Student-Teachers' Conseptual Understanding of the Greenhouse Effect: A Mixed Method Study', International Journal of Science Education, 1.July (2012), 1-46.

3 M. Kişoğlu and others, 'Prospective Turkish Elementary Science Teachers' Knowledge Level about the Greenhouse Effect and Their Views
Untuk guru Sekolah Dasar, tantangannya adalah bagaimana mengajarkan tentang perubahan energi dengan cara-cara yang praktis yang berisi mengenai pengetahuan mendalam dan pemahaman mendalam tentang konsep perubahan energi. Dalam sistem pendidikan di Indonesia, siswa Sekolah Dasar yang terlibat dalam pembelajaran tematik sains perlu diberikan arahan dan fokus bagaimana mengembangkan pengalaman belajar bagi siswa Sekolah Dasar secara menyeluruh ${ }^{4}$.

Beberapa penelitian mengungkapkan bahwa pengetahuan awal siswa Sekolah Dasar berkaitan dengan topik-topik sains dan konsep lingkungan ${ }^{5}$.

Atas dasar tersebutlah peneliti mencoba melakukan penelitian mengenai perubahan energi dikarenakan berkaitan dengan lingkungan. Hal tersebut juga menarik untuk siswa dimana mereka bisa mengetahui, yang tidak tahu menjadi tahu dan sebagian tahu menjadi tahu tentang konsep sains yang berkaitan dengan perubahan energi sebagai langkah pertama dalam pembelajaran penemuan yang berkualitas ${ }^{6}$.

Penelitian ini mencoba menerapkan

on Environmental Education in University', International Electronic Journal of Elementary Education, 2.2 (2010), 217-36.

${ }^{4}$ R. Duit and D. Treagust, 'Conseptual Change: A Powerful Framework for Improving Science Teaching and Learning', International Journal of Science Education, 25.6 (2003), 671-88.

5 R. Ballantyne, 'Teaching Environmental Concepts, Attitudes and Behaviour Through Geography Education: Findings of an International Survey', International Research in Geographical and Environmental Education, $8.1 \quad$ (1999), 40-58 <https://doi.org/10.1080/10382049908667588>.

${ }^{6}$ Alberta, Focus on Inquiry: A Teacher's Guide to Implementing Inquiry-Based Learning, 2004. 
metode pembelajaran penemuan. Melalui metode penemuan, pembelajaran akan lebih menarik bagi siswa karena mereka belajar dengan cara membangun dari apa yang siswa ketahui dan memberikan kesempatan untuk terlibat dalam praktik pembelajaran yang akan memberikan pengalaman yang menyebabkan siswa Sekolah Dasar mengembangkan pemahaman baru dan lebih dalam ${ }^{7}$.

Pengetahuan siswa tentang energi di seluruh dunia masih menganggap energi sebagai berikut: energi adalah jenis bahan bakar umum yang bekerja untuk manusia, energi itu berhubungan dengan makhluk hidup dan berpusat pada manusia, energi itu berhubungan dengan memindahkan benda, misalnya api, mobil, telepon berdering, energi itu dapat mengambil bentuk yang berbeda saat perjalanan melalui kabel atau rantai sepeda, energi merupakan sumber kekuatan atau aktivitas yang tersimpan dalam objek, misalnya, air memiliki energi didalamnya sehingga dapat memutar roda air, energi merupakan gudang yang digunakan untuk membuat segala sesuatu bekerja seperti baterai, energi juga dapat diperoleh dari makanan, tubuh, matahari, dan tanah, itu dianggap sebagai bahan yang disimpan didalamnya, energi juga merupakan bahan seperti cairan yang mengalir dari satu tubuh ke yang lain, sebagai arus listrik atau aliran, dan energi juga dibebaskan seperti produk limbah, misalnya, bahan kimia mengeluarkan panas ${ }^{8}$.

Dari serangkaian pengamatan ini, jelas bahwa siswa-siswa memang

${ }^{7}$ N. Ismail and R. Abu, 'Implementing Inquiry-Based Learning: An Innovative Method for Proactive Students', in 12th International Conference on Education Universiti Brunei Darussalam, 2007, pp. 259-68.

${ }^{8}$ N. S. Evans, H. Whitehouse, and R. Hickey, 'Pre-Service Teachers' Conceptions of Education for Sustainability', Australian Journal of Teacher Education, $37.7 \quad$ (2012), 1-12 <https://doi.org/10.14221/ajte.2012v37n7.3>. memberikan berbagai gagasan tentang sifat dan perubahan energi. Keragaman tersebut belum nampak pada siswa-siswa di Sekolah Dasar, dan hal tersebut perlu diteliti dan dilaporkan melalui penelitian.

Ketekunan ilmiah dan pemahaman nonilmiah tentang perubahan energi juga telah terbukti dapat melampaui sekolah. Analisis peneliti-peneliti sebelumnya, diungkapkan bahwa sejumlah kesalahpahaman yang terusmenerus dilakukan oleh para calon guru Sekolah Dasar sebagai berikut: sebagian besar berpikir bahwa energi adalah entitas konkret, sebagian besar tidak menerima gagasan konservasi energi, ambigu dalam pengakuan mereka terhadap berbagai jenis energi, sebagian besar bingung tentang konsep energi dan kekuatan

Dalam penelitian yang dilaporkan dalam artikel ini, hubungan yang lebih spesifik antara energi dan isu-isu terkait lingkungan adalah fokus utama. Sangat sedikit literatur penelitian yang ditemukan yang secara khusus membahas tentang siswa Sekolah Dasar mengenai pemahaman konsep seperti sumber energi dan sumber energi terbarukan dan tidak terbarukan. Sangat sedikit penelitian yang dilakukan untuk mencari tahu apa yang siswa ketahui tentang konsep-konsep lingkungan.

Satu studi melaporkan bahwa baik siswa Sekolah Dasar dan orang dewasa, pemahaman tentang konsep-konsep lingkungan, termasuk perubahan energi sering salah serta sangat gigih untuk mengajar intervensi ${ }^{10}$.

Melalui penelitian ini, peneliti berusaha untuk menjelaskan pemahaman konseptual ilmu pengetahuan mendalam yang dipegang oleh para calon guru Sekolah Dasar. Artikel ini juga berisi mengenai konsep perubahan energi dalam berbagai bentuknya (radiasi elektromagnetik, panas, dan kimia) adalah konsep yang sulit dipahami oleh siswa Sekolah Dasar.

9 B. Lefa, 'The Piaget Theory of Cognitive Development: An Educational Implications', Research Gate, 1.9 (2014), 1-9.

${ }^{10}$ R. Mellors-Bourne, 'The Wider Benefits of Transnational Education to the UK', Social Science in Government, July, 2017, 1-80. 
Berdasarkan latar belakang yang telah diungkapkan sebelumnya, maka penelitian ini diarahkan untuk menjawab permasalahan sebagai berikut: “Bagaimana pengetahuan siswa pada bahasan perubahan energi melalui pembelajaran penemuan di Sekolah Dasar?". Permasalahan tersebut kami rinci melalui pertanyaan penelitian sebagai berikut: “Apakah siswa Sekolah Dasar mampu mengenali perbedaan antara istilah-istilah lingkungan seperti perubahan energi, efek rumah kaca, dan pemanasan global?".

Berdasarkan rumusan masalah yang telah diungkapkan, maka perlu adanya batasan-batasan penelitian agar penelitian ini lebih terarah. Batasan-batasan penelitian yang diberikan sebagai berikut: 1). Penelitian ini dibatasi pada siswa Sekolah Dasar kelas IV; 2). Subyek penelitian adalah siswa Sekolah Dasar; Indikator yang diukur adalah pengetahuan siswa Sekolah Dasar mengenai perubahan energi dalam pembelajaran penemuan melalui lembar pertanyaaan yang dijawab siswa dan lembar pengamatan dalam bentuk uraian/deskripsi. Tujuan dari penelitian ini adalah untuk mengetahui pengetahuan siswa mengenai perubahan energi dalam pembelajaran sains melalui metode penemuan.

Target luaran yang diharapkan pada kegiatan penelitian ini sebagai berikut: 1 ). Tersedianya instrumen yang valid dan reliabel untuk mengukur pengetahuan siswa Sekolah Dasar mengenai perubahan energi; 2). Hasil-hasil penelitian yang bisa dijadikan bahan sebagai data-data dan fakta saat kegiatan ini dilakukan, bisa menjadi bahan kajian lanjutan untuk bahan kajian penyelesaian tugas akhir dan bisa dipublikasikan secara nasional melalui jurnal-jurnal pendidikan yang tersedia; 3). Sebagai bahan kajian, adapun program penelitian tindak lanjut yang bisa dilakukan sebagai berikut: bertambahnya siswa dan guru-guru Sekolah Dasar dalam mengembangkan keterampilan pembelajaran melalui metode penemuan; 4). Tersosialisasinya program penelitian kolaborasi dosen dan mahasiswa yang bisa memperkenalkan program ini semakin luas lagi sebagai bentuk hasil dari pelaksanaan program dan juga dapat melibatkan guru-guru pada Sekolah-sekolah Dasar mitra sekitar; 5). Adanya peningkatan pengetahuan siswa Sekolah Dasar tentang perubahan energi.

\section{Metode}

Metode penelitian yang digunakan adalah metode penelitian deskriptif kuantitatif ${ }^{11}$. Sampel penelitian ini berjumlah 43 siswa Sekolah Dasar yang terdiri dari 28 siswa lakilaki dan 15 siswa perempuan.

Instrumen mengenai survei perubahan energi dirancang menggunakan pedoman untuk menetapkan apa yang sebelumnya dipahami oleh siswa. Pertanyaan-pertanyaan spesifik dalam survei dikembangkan menurut hasil belajar dan analisis silabus dalam tematik sains siswa Sekolah Dasar.

Pertanyaan-pertanyaan yang dirancang untuk menentukan tingkat pengetahuan siswa berupa pertanyaan-pertanyaan tentang konsep-konsep perubahan energi dan sumber energi terbarukan dan tidak terbarukan. Pengamatan dilakukan untuk mengetahui cara guru memberikan pertanyaan, jenis pertanyaan, dan jawaban yang diberikan oleh siswa ${ }^{12}$.

Penelitian ini menggunakan jenis penelitian deskripstif kuantitatif dimana 43 siswa berpartisipasi dalam program hemat energi pada pembelajaran tahun 2018 disurvei dan dianalisis. Secara keseluruhan, tingkat respons terhadap pertanyaan individu pada

${ }^{11}$ B. L Berg, Qualitative Research Methods for the Social Sciences (London: Pearson, 2007).

${ }_{12}$ M Aziza, 'An Analysis of a Teacher's Questioning Related to Students' Responses and Mathematical Creativity in an Elementary School in the UK', International Electronic Journal of Elementary $\begin{array}{llll}\text { Education, } & 10.4 & \text { (2018), } & 475-87\end{array}$ <https://doi.org/10.26822/iejee.2018438138>. 
pelaksanaan survey termasuk dalam kategori tinggi (responden minimum per pertanyaan $90 \%$ ).

Lokasi penelitian yang digunakan adalah SD Pahlawan, Jalan Ridan Permai Kecamatan Bangkinang Kota Kabupaten Kampar dengan jumlah subyek penelitian 43 siswa Sekolah Dasar kelas IV. Peubah yang diamati atau diukur dalam penelitian ini adalah pengetahuan siswa mengenai perubahan energi yang teramati pada lembar jawaban yang diberikan dan pada saat pembelajaran sains dilakukan.

Model yang digunakan dalam penelitian ini adalah model pembelajaran penemuan. Analisis statistik yang digunakan adalah statistik deskriptif dan tes Chi-square untuk menentukan apakah terdapat perbedaan pola respon diantara kelompok-kelompok siswa yang diteliti. Analisis ini dibantu menggunakan software SPSS versi 19. Tahapan penelitian digambarkan melalui bagan sebagai berikut:

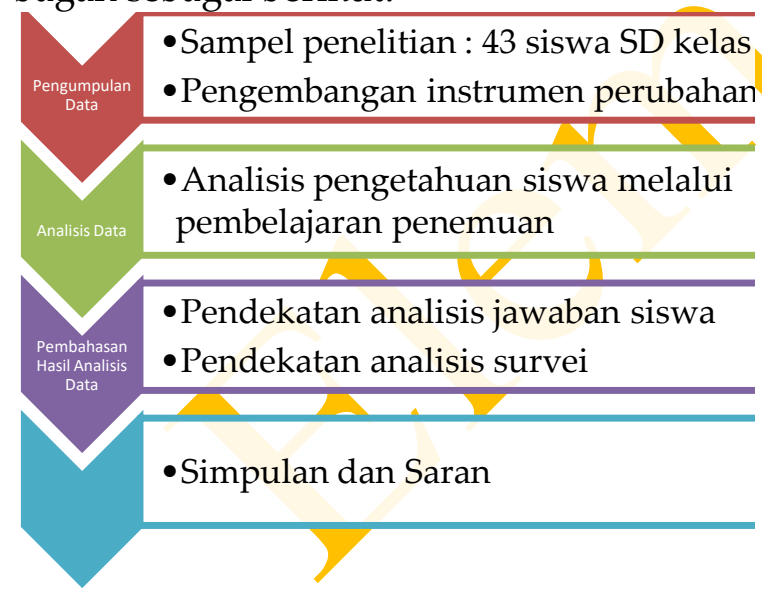

\section{Bagan 1. Tahapan Penelitian}

\section{Hasil dan Pembahasan}

Tanggapan siswa pada setiap pertanyaan disajikan pada Tabel 1 berikut:

Tabel 1. Tanggapan mengenai Perubahan Energi

\begin{tabular}{|l|l|l|}
\hline $\begin{array}{l}\text { Pertanyaan- } \\
\text { pertanyaan }\end{array}$ & $\begin{array}{l}\text { Pilihan } \\
\text { Tanggapan }\end{array}$ & $\begin{array}{l}\text { Jumlah } \\
\text { Siswa }\end{array}$ \\
\hline $\begin{array}{l}\text { Apakah cahaya } \\
\text { berasal dari energi } \\
\text { sejenis bohlam/bola }\end{array}$ & Ya Tidak & 42 \\
\hline
\end{tabular}

\begin{tabular}{|c|c|c|}
\hline $\begin{array}{l}\text { Pertanyaan- } \\
\text { pertanyaan }\end{array}$ & $\begin{array}{l}\text { Pilihan } \\
\text { Tanggapan }\end{array}$ & $\begin{array}{l}\text { Jumlah } \\
\text { Siswa }\end{array}$ \\
\hline \multicolumn{3}{|l|}{ lampu? } \\
\hline $\begin{array}{l}\text { Apakah manusia } \\
\text { menggunakan energi } \\
\text { saat ia berlari? }\end{array}$ & $\begin{array}{ll}\text { a. } & \text { Ya } \\
\text { b. } & \text { Tidak }\end{array}$ & $\begin{array}{l}42 \\
1\end{array}$ \\
\hline $\begin{array}{l}\text { Suara yang keluar } \\
\text { dari radio merupakan } \\
\text { salah satu bentuk } \\
\text { energi? }\end{array}$ & $\begin{array}{ll}\text { a. } & \text { Ya } \\
\text { b. } & \text { Tidak }\end{array}$ & $\begin{array}{l}30 \\
13\end{array}$ \\
\hline $\begin{array}{l}\text { Jenis energi apa yang } \\
\text { dihasilkan dari kayu } \\
\text { terbakar? }\end{array}$ & $\begin{array}{ll}\text { a. } & \text { Listrik } \\
\text { b. } & \text { Panas } \\
\text { c. } & \text { Cahaya } \\
\text { d. } & \text { Cahaya } \\
& \text { dan } \\
& \text { panas } \\
\end{array}$ & $\begin{array}{l}0 \\
12 \\
2 \\
29\end{array}$ \\
\hline $\begin{array}{l}\text { Energi dalam tubuh } \\
\text { kita berasal dari? }\end{array}$ & $\begin{array}{l}\text { a. Tidur } \\
\text { b. Makan } \\
\text { c. Minum }\end{array}$ & $\begin{array}{l}14 \\
25 \\
4 \\
\end{array}$ \\
\hline $\begin{array}{lr}\text { Di planet } & \text { Bumi kita, } \\
\text { semua } & \text { hidup } \\
\text { tergantung } & \text { pada } \\
\text { Matahari } & \text { untuk } \\
\text { energinya, betul atau } \\
\text { tidak? }\end{array}$ & $\begin{array}{l}\text { a. Ya } \\
\text { b. Tidak }\end{array}$ & $\begin{array}{l}42 \\
1\end{array}$ \\
\hline
\end{tabular}

Pertanyaan 1-3 dirancang untuk mengungkapkan apa yang diketahui siswa tentang jenis energi. Pertanyaan 4-6 bertanya kepada siswa tentang darimana energi berasal.

Secara keseluruhan, hasil penelitian menunjukkan bahwa siswa Sekolah Dasar cukup tahu banyak tentang berbagai jenis energi. Dalam pertanyaan 1, secara keseluruhan 42 dari 43 siswa menjawab dengan benar pertanyaan ini. Pada pertanyaan 2, mayoritas siswa (98\%) berhasil mengungkapkan bahwa ketika seseorang sedang berlari, energi sedang dikeluarkan/dikonsumsi. Siswa laki-laki lebih sering benar daripada siswa perempuan dalam mengenali bahwa orang tersebut menggunakan energi saat berlari ${ }^{13}$.

Pertanyaan ketiga mengungkapkan bahwa 30 dari 43 siswa dengan benar tahu bahwa

13 M. Karpudewan, W. M. Roth, and K. Chandrakesan, 'Remediating Misconception on Climate Change among Secondary School Students in Malaysia', Environmental Education Research, 21.4 (2015), 631-48 <https://doi.org/10.1080/13504622.2014.891004>. 
suara yang berasal dari radio adalah salah satu bentuk energi. Siswa yang usianya sedikit lebih muda banyak yang menjawab benar. Temuan ini menunjukkan bahwa siswa sekolah dasar yang usianya lebih muda ini memiliki pemahaman sebelumnya tentang energi suara yang berbeda dengan penjelasan ilmiah yang diterimanya. Temuan ini juga dapat dihubungkan kembali ke silabus pembelajaran sekolah dasar sebagai masukan dalam pembelajaran dimana produksi suara dan energi adalah konsep yang pertama kali diperkenalkan dalam fenomena fisik ${ }^{14}$.

Tiga pertanyaan berikutnya yang diperiksa adalah apa yang siswa ketahui dan darimana energi berasal. Pertanyaanpertanyaan ini mengacu pada beberapa kesalahpahaman yang telah diidentifikasi. Pertanyaan 4 mengharuskan siswa untuk mengetahui bahwa cahaya dan energi panas dihasilkan ketika kayu terbakar. Sangat menyenangkan untuk melaporkan bahwa tidak ada siswa yang memilih energi listrik sebagai produk dari kayu yang terbakar. Bahkan, 29 dari 43 siswa (68\%) mengetahui bahwa energi cahaya dan energi panas dihasilkan. Hampir semua siswa yang tersisa (28\%) menyatakan bahwa hanya energi panas yang dihasilkan.

Kesalahpahaman bahwa membakar kayu dalam api tidak menghasilkan energi cahaya adalah topik yang perlu guru Sekolah Dasar tanamkan ketika mengajar tentang pembakaran. Kesalahpahaman ini sangat persisten dan konsisten ${ }^{15}$.

${ }^{14}$ R. Lane and P. Coutts, 'Working with Students ' Ideas in Physical Geography: A Model of Knowledge Development and Application', Geographical Education, 28.December (2015), 2740.

15 R. Lane, 'Experienced Geography Teachers' PCK of Students' Ideas and Beliefs about Learning and Teaching', International Research in Geographical and Environmental Education, 24.1 (2015),

43-57
Pertanyaan 5 bertanya tentang apa yang siswa ketahui tentang darimana energi yang digunakan dalam tubuh kita berasal. Tanggapan terhadap pertanyaan ini mengungkapkan serangkaian hasil yang mengejutkan dan tak terduga. Sekitar 14 dari 43 siswa (41\%) percaya bahwa tidur adalah tempat energi dalam tubuh kita berasal. Demikian pula hampir 4 dari 43 siswa (9\%) percaya bahwa air minum memasok energi yang diperlukan tubuh kita. Lebih dari sepertiga dari siswa (58\%) dengan benar menyatakan bahwa melalui makan makanan tubuh kita memperoleh energi yang mereka butuhkan. Temuan ini menunjukkan bahwa mayoritas siswa memiliki pengetahuan alternatif tentang asal-usul energi dalam tubuh kita ${ }^{16}$.

Untuk guru Sekolah Dasar, tubuh dan makanan adalah topik umum yang diajarkan di kelas sains dasar, mereka perlu membuat hubungan yang lebih eksplisit antara makanan sebagai sumber energi dan bagaimana tubuh kita memproses makanan untuk menyediakan energi yang diperlukan untuk sel dan fungsi tubuh agar bekerja normal ${ }^{17}$.

Pertanyaan terakhir mengungkapkan bahwa mayoritas siswa (98\%) tahu bahwa matahari adalah sumber energi untuk semua kehidupan di Bumi. Temuan ini konsisten ${ }^{18}$.

Untuk mengeksplorasi lebih jauh, pertanyaan 7 mengenai sumber energi terbarukan dan tidak terbarukan diberikan kepada siswa. Bagaimana pengetahuan dan pemahaman siswa tentang berbagai sumber energi terbarukan atau tidak terbarukan secara khusus dieksplorasi. Berikut tanggapan siswa:

<https://doi.org/10.1080/10382046.2014.967113>.

16 E. J. Francois, M. B.M. Avoseh, and W. Griswold, Perspectives in Transnational Higher Education, Sense Publishers, 2016 <https://doi.org/10.1007/978-94-6300-420-6>.

17 NESA, NSW Syllabus for the Australian Curriculum Science and Technology K-6 Syllabus, 2017.

${ }^{18} \mathrm{R}$. Lynes, TRANSNATIONAL EDUCATION A GUIDE FOR CREATING PARTNERSHIPS IN INDIA, 2015. 
Tabel 2. Sumber Energi Terbarukan dan Tidak Terbarukan

\begin{tabular}{|c|c|c|}
\hline $\begin{array}{l}\text { Pertanyaan- } \\
\text { pertanyaan }\end{array}$ & $\begin{array}{l}\text { Pilihan } \\
\text { Tanggapan }\end{array}$ & $\begin{array}{l}\text { Jumlah } \\
\text { Siswa }\end{array}$ \\
\hline $\begin{array}{l}\text { Listrik } \\
\text { tenaga air }\end{array}$ & $\begin{array}{l}\text { a. Terbarukan } \\
\text { b. Tidak } \\
\text { terbarukan }\end{array}$ & $\begin{array}{l}22 \\
21\end{array}$ \\
\hline Batu bara & $\begin{array}{l}\text { a. Terbarukan } \\
\text { b. Tidak } \\
\text { terbarukan }\end{array}$ & $\begin{array}{l}20 \\
23\end{array}$ \\
\hline Gas alam & $\begin{array}{ll}\text { a. Terbarukan } \\
\text { b. Tidak } \\
\text { terbarukan }\end{array}$ & $\begin{array}{l}20 \\
23\end{array}$ \\
\hline Nuklir & $\begin{array}{ll}\text { a. } & \text { Terbarukan } \\
\text { b. Tidak } \\
\text { terbarukan }\end{array}$ & $\begin{array}{l}22 \\
21 \\
\end{array}$ \\
\hline Makanan & $\begin{array}{l}\text { a. Terbarukan } \\
\text { b. Tidak } \\
\text { terbarukan }\end{array}$ & $\begin{array}{l}22 \\
21 \\
\end{array}$ \\
\hline $\begin{array}{l}\text { Listrik } \\
\text { tenaga surya }\end{array}$ & $\begin{array}{ll}\text { a. } & \text { Terbarukan } \\
\text { b. Tidak } \\
\text { terbarukan }\end{array}$ & $\begin{array}{l}43 \\
0 \\
\end{array}$ \\
\hline $\begin{array}{l}\text { Minyak/bens } \\
\text { in }\end{array}$ & $\begin{array}{ll}\text { a. } & \text { Terbarukan } \\
\text { b. Tidak } \\
\text { terbarukan }\end{array}$ & $\begin{array}{l}20 \\
23 \\
\end{array}$ \\
\hline Tenaga angin & $\begin{array}{ll}\text { a. } & \text { Terbarukan } \\
\text { b. Tidak } \\
\text { terbarukan }\end{array}$ & $\begin{array}{l}41 \\
2 \\
\end{array}$ \\
\hline
\end{tabular}

Secara keseluruhan, banyak gagasan siswa Sekolah Dasar tentang sumber energi mana yang dapat diperbaharui dan yang tidak terbarukan mengungkapkan kebingungan yang cukup besar. Rata-rata 22 dari 43 siswa menjawab dengan benar untuk pembangkit listrik tenaga air menjadi sumber energi terbarukan. Begitu juga dengan batubara sebagai energi tidak terbarukan dengan 23 dari 43 siswa menjawab benar.

Tanggapan yang diberikan untuk gas alam lebih menarik dengan hanya 23 dari 43 siswa yang memahami bahwa gas alam adalah sumber energi yang tidak terbarukan. Kesalahpahaman tentang gas alam menjadi sumber energi terbarukan mungkin sebagian karena kata alam.

Siswa menafsirkan alami sebagai dapat diperbarui. Rata-rata 22 dari 43 siswa percaya nuklir adalah sumber energi terbarukan. Setelah penyelidikan lebih lanjut, perbedaan yang signifikan ditemukan pada bagaimana siswa dapat memahami contoh ini 19 .

Respon siswa Sekolah Dasar terhadap nuklir ini masih menekankan bahwa 21 dari 43 siswa tidak menyadari bahwa nuklir adalah sumber energi tak terbarukan. Implikasinya bagi guru ketika mengajar tentang jenis sumber energi dan apakah mereka dapat diperbarui atau tidak terbarukan sudah jelas. Pertimbangan rinci tentang bagaimana dan dimana nuklir berasal dari kebutuhan untuk dimasukkan dalam urutan pembelajaran ${ }^{20}$.

Menentukan apakah makanan merupakan sumber energi yang terbarukan atau tidak terbarukan juga merupakan pertanyaan yang mengungkap siswa memiliki kesalahpahaman. Antara 22 siswa di setiap 43 siswa mengidentifikasi makanan dengan benar sebagai sumber energi terbarukan. Temuan ini ketika dikaitkan dengan jawaban pertanyaan 5 menunjukkan bahwa secara holistik tingkat pemahaman tentang makanan sebagai sumber energi dan apakah makanan merupakan sumber terbarukan atau tidak terbarukan tidak selaras dengan pemahaman ilmiah yang diterima ${ }^{21}$.

Satu penjelasan yang mungkin untuk tingkat kesalahpahaman yang tinggi terkait dengan pertanyaan ini adalah bahwa siswa tidak menghubungkan makan makanan dengan rantai makanan, aliran energi, dan siklus hidup. Lebih lanjut, siswa mungkin berpikir bahwa makanan harus tidak terbarukan karena ketika memakannya, itu hilang.

${ }^{19}$ I. Hussain, 'Transnational Education: Concept and Methods', Turkish Online Journal of Distance Education, 8.1 (2007), 163-73.

${ }^{20} \mathrm{~J}$. W. McBride and others, 'Using an Inquiry Approach to Teach Science to Secondary School Science Teachers', Physics Education, 39.5 (2004), 1-6 <https://doi.org/10.1088/0031-9120/39/5/007>.

21 P. Cuevas and others, 'Improving Science Inquiry with Elementary Students of Diverse Backgrounds', Journal of Research in Science Teaching, 42.3 (2005), 337-57 <https://doi.org/10.1002/tea.20053>. 
Listrik tenaga surya menghasilkan tingkat respons yang paling sukses dengan 43 siswa yang memahami bahwa itu adalah sumber energi terbarukan. Tingkat respons yang tinggi dapat dikaitkan dengan fokus media yang tinggi pada tenaga surya menjadikannya sebagai topik hangat saat ini. Namun, konsumsi minyak/bensin juga merupakan media prioritas tinggi, namun hanya sekitar 23 dari 43 siswa menjawab dengan benar bahwa mereka memahami minyak/bensin adalah sumber energi tak terbarukan.

Contoh terakhir mengungkapkan bahwa 41 dari setiap 43 siswa mengakui listrik yang dihasilkan oleh angin sebagai sumber energi terbarukan. Tanggapan ini konsisten di semua siswa.

\section{Kesimpulan}

Artikel ini bertujuan untuk melaporkan penyelidikan yang dirancang untuk menetapkan apa yang diketahui siswa Sekolah Dasar tentang sumber energi, perubahan energi, dan sumber energi terbarukan dan tak terbarukan. Temuan ini mengungkapkan bahwa gagasan siswa tentang jenis energi masih berkembang dengan pemahaman siswa Sekolah Dasar tentang energi yang mengungkapkan beberapa kesalahpahaman yang terus menerus.

Lebih lanjut, sebagian besar siswa di Sekolah Dasar Pahlawan menyadari bahwa matahari adalah sumber energi utama untuk semua kehidupan di bumi, tetapi banyak siswa yang memegang kesalahpahaman tentang makanan sebagai sumber energi bagi manusia. Hampir setengah dari siswa mengalami kesalahpahaman khususnya tentang sumber energi terbarukan dan tidak terbarukan.

Untuk guru Sekolah Dasar, penelitian ini menyarankan strategi untuk membantu siswa secara terbuka dalam mempertimbangkan ide terselubung mereka tentang energi dan perubahan energi, juga kebutuhan secara eksplisit dalam membelajarkan konsep-konsep ini dalam konteks dunia nyata.

Hasil penelitian ini lebih menyoroti praktik pedagogis yang penting untuk menetapkan ide apa yang telah dimiliki siswa tentang konsep pada rencana pembelajaran mereka dan mengembangkan program pembelajaran yang responsif untuk mengembangkan pemahaman mendalam tentang konsep perubahan energi. Survei energi dan perubahan energi yang dikembangkan dan digunakan dalam penelitian ini memberikan satu strategi yang mudah digunakan yang dapat diterapkan oleh guru Sekolah Dasar untuk membantu mereka dalam menemukan konsep dan miskonsepsi siswa Sekolah Dasar di kelas mereka.

\section{Daftar Pustaka}

Alberta, Focus on Inquiry: A Teacher's Guide to Implementing Inquiry-Based Learning, 2004

Aziza, M, 'An Analysis of a Teacher's Questioning Related to Students' Responses and Mathematical Creativity in an Elementary School in the UK', International Electronic Journal of Elementary Education, $10.4 \quad$ (2018), 475-87 <https://doi.org/10.26822/iejee.2018438138>

Ballantyne, R., 'Teaching Environmental Concepts, Attitudes and Behaviour Through Geography Education: Findings of an International Survey', International Research in Geographical and Environmental Education, $8.1 \quad$ (1999), 40-58 $<$ https://doi.org/10.1080/10382049908667588

$$
>
$$

Berg, B. L, Qualitative Research Methods for the Social Sciences (London: Pearson, 2007)

BOYLAN, C., 'Exploring Elementary Students' Understanding of Energy and Climate Change', International Electronic Journal of Elementary Education, 1.1 (2008), 1-15

Cuevas, P., O. Lee, J. Hart, and R. Deaktor, 'Improving Science Inquiry with 
Elementary Students of Diverse Backgrounds', Journal of Research in Science Teaching, 42.3 (2005), 337-57 $<$ https://doi.org/10.1002/tea.20053>

Duit, R., and D. Treagust, 'Conseptual Change: A Powerful Framework for Improving Science Teaching and Learning', International Journal of Science Education, 25.6 (2003), 671-88

Evans, N. S., H. Whitehouse, and R. Hickey, 'Pre-Service Teachers' Conceptions of Education for Sustainability', Australian Journal of Teacher Education, 37.7 (2012), 1-12 $<$ https://doi.org/10.14221/ajte.2012v37 n7.3>

Francois, E. J., M. B.M. Avoseh, and W. Griswold, Perspectives in Transnational Higher Education, Sense Publishers, 2016 $<$ https://doi.org/10.1007/978-94-6300420-6>

Hussain, I., 'Transnational Education: Concept and Methods', Turkish Online Journal of Distance Education, 8.1 (2007), 163-73

Ismail, N., and R. Abu, 'Implementing Inquiry-Based Learning: An Innovative Method for Proactive Students', in 12th International Conference on Education Universiti Brunei Darussalam, 2007, pp. 259-68

Karpudewan, M., W. M. Roth, and K. Chandrakesan, 'Remediating Misconception on Climate Change among Secondary School Students in Malaysia', Environmental Education Research, $21.4 \quad$ (2015), 631-48 $<$ https://doi.org/10.1080/13504622.2014 $.891004>$

Kişoğlu, M., H. Gürbüz, M. Erkol, M. S. Akar, and M. Akilli, 'Prospective Turkish Elementary Science Teachers' Knowledge Level about the Greenhouse Effect and Their Views on Environmental Education in
University', International Electronic Journal of Elementary Education, 2.2 (2010), 217-36

Lane, R., 'Experienced Geography Teachers' PCK of Students' Ideas and Beliefs about Learning and Teaching', International Research in Geographical and Environmental Education, $24.1 \quad$ (2015), 43-57 $<$ https://doi.org/10.1080/10382046.2014.9671 13>

Lane, R., and P. Coutts, 'Working with Students ' Ideas in Physical Geography: A Model of Knowledge Development and Application', Geographical Education, 28.December (2015), 27-40

Lefa, B., 'The Piaget Theory of Cognitive Development: An Educational Implications', Research Gate, 1.9 (2014), 1-9

Lynes, R., TRANSNATIONAL EDUCATION A GUIDE FOR CREATING PARTNERSHIPS IN INDIA, 2015

McBride, J. W., M. I. Bhatti, M. A. Hannan, and M. Feínberg, ‘Using an Inquiry Approach to Teach Science to Secondary School Science Teachers', Physics Education, 39.5 (2004), 1-6 $<$ https://doi.org/10.1088/0031-

9120/39/5/007>

Mellors-Bourne, R., 'The Wider Benefits of Transnational Education to the UK', Social Science in Government, July, 2017, 1-80

NESA, NSW Syllabus for the Australian Curriculum Science and Technology K-6 Syllabus, 2017

Ratinen, I. J., 'Primary Student-Teachers' Conseptual Understanding of the Greenhouse Effect: A Mixed Method Study', International Journal of Science Education, 1.July (2012), 1-46 